\title{
Intrinsic (gas-phase) acidity and basicity of paracetamol
}

\author{
Juan Z. Dávalos, ${ }^{\mathrm{a}}{ }^{\mathrm{a}}$ Javier González, ${ }^{\mathrm{a}}$ Rocío Ramos, ${ }^{\mathrm{a}}$ Andrés Guerrero, ${ }^{\mathrm{a}}$ \\ and Alexsandre F. Lago ${ }^{b}$ \\ ${ }^{a}$ Instituto de Química Física Rocasolano, CSIC. c/Serrano, 119.E-28006 Madrid, Spain. \\ ${ }^{\mathrm{b}}$ Centro de Ciencias Naturais e Humanas, Universidade Federal do ABC, 09210-170 Santo \\ André, SP, Brazil \\ E-mail:jdavalos@iqfr.csic.es
}

Dedicated to Professor Rosa Maria Claramunt on the occasion of her $65^{\text {th }}$ birthday

\begin{abstract}
Gas phase protonation enthalpy (proton affinity) and deprotonation enthalpy of paracetamol, $P A$ $=909.4 \pm 8.4 \mathrm{~kJ} \cdot \mathrm{mol}^{-1}$ and $\Delta_{\text {acid }} H^{0}=1430.3 \pm 8.8 \mathrm{~kJ} \cdot \mathrm{mol}^{-1}$, have been experimentally determined by the extended kinetic method (EKM) using ESI-triple-quadrupole mass spectrometry. Gas phase basicity and acidity deduced from these experiments, $G B=869.9 \pm 8.4 \mathrm{~kJ} \cdot \mathrm{mol}^{-1}$ and $G A=$ $1404.7 \pm 8.8 \mathrm{~kJ} \cdot \mathrm{mol}^{-1}$ are in good agreement with calculations performed at the B3LYP level of theory with 6-311++G(3df,2p) and 6-311++G(d,p) basis sets. We also have derived the enthalpy of formation of deprotonated $\left(\Delta_{\mathrm{f}} H^{0}(\mathrm{~g})=-386.4 \pm 9.0 \mathrm{~kJ} \cdot \mathrm{mol}^{-1}\right)$ and protonated $\left(\Delta_{\mathrm{f}} H^{0}(\mathrm{~g})=346.3\right.$ $\left.\pm 8.6 \mathrm{~kJ} \cdot \mathrm{mol}^{-1}\right)$ paracetamol ions.
\end{abstract}

Keywords: Paracetamol, acidity, basicity, ESI-MS, Extended Kinetic Method, DFT

\section{Introduction}

Paracetamol (acetaminophen, $p$-acetamidophenol, N-(4-hydroxyphenyl) acetamide, $\mathrm{C}_{8} \mathrm{H}_{9} \mathrm{O}_{2} \mathrm{~N}$, (Structure 1) is probably the most versatile chemical compound and used worldwide in drug formulations of analgesic, anti-inflamatory and antipyretic. The polymorphic forms, in solid state, of this compound have been widely studied..$^{1-4}$

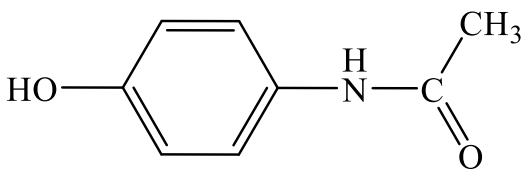

\section{Structure 1}


Although the thermochemical properties of paracetamol neutral molecule have been determined, ${ }^{5}$ knowledge of the quantitative information of the gas phase energetic properties is practically absent. The present study was undertaken with the goal to bring information on the acidity (deprotonation), basicity (protonation) and structural features of paracetamol. For this purpose, experiments were done using a triple-quadrupole mass spectrometer equipped with an electrospray source (ESI). The data were treated by the extended kinetic method (EKM) ${ }^{6-14}$ which provide the deprotonation and protonation thermodynamic quantities associated with the general reactions (1) and (2), respectively.

The intrinsic (gas-phase) acidity and basicity of paracetamol were also calculated by DFT method using B3LYP functional with 6-311+G(d,p) and 6-311+G(3df,2p) basis sets, which are known ${ }^{15,16}$ to reproduce very well the experimental results.

The gas-phase acidity (or merely acidity) of a protic acid $\mathrm{AH}, G A(\mathrm{AH})$, and the basicity of a base $\mathrm{B}, G B(\mathrm{~B})$, are defined as the Gibbs free-energy change for reactions (1) and (2), respectively:

$$
\begin{array}{ll}
\mathrm{AH}(\mathrm{g}) \rightarrow \mathrm{A}^{-}(\mathrm{g})+\mathrm{H}^{+}(\mathrm{g}) & \Delta_{\mathrm{acid}} G^{0}(1)=G A, \Delta_{\mathrm{acid}} H^{0}(1), \Delta_{\mathrm{acid}} S^{0}(1) \\
\mathrm{BH}^{+}(\mathrm{g}) \rightarrow \mathrm{B}(\mathrm{g})+\mathrm{H}^{+}(\mathrm{g}) & \Delta_{\mathrm{p}} G^{0}(2)=G B, P A=\Delta_{\mathrm{p}} H^{0}(2), \Delta_{\mathrm{p}} S^{0}(2)
\end{array}
$$

The corresponding enthalpy and entropy changes for reaction (1) are referred to as gas-phase deprotonation enthalpy $\left(\Delta_{\text {acid }} H^{0}\right)$ and deprotonation entropy $\left(\Delta_{\text {acid }} S^{0}\right)$, respectively; while for reaction (2) its enthalpy and entropy are called, respectively, proton affinity $(P A)$ and protonation entropy, $\left(\Delta_{\mathrm{p}} S^{0}\right)$.

\section{Results and Discussion}

\section{Extended Kinetic method (EKM)}

The extended kinetic method $(\mathrm{EKM})^{6-14}$ is an improved version of the simple Cooks kinetic method ${ }^{17-20}$ which takes into account entropic effects on the competitive dissociations of a massselected proton-bound heterodimer (cluster-) anions $\left[\mathrm{A} \cdot \mathrm{H} \cdot \mathrm{A}_{\mathrm{ref}(\mathrm{i})}\right]^{-}$(acidity case) or (cluster) cations $\left[\mathrm{B} \cdot \mathrm{H} \cdot \mathrm{B}_{\mathrm{ref}(\mathrm{i})}\right]^{+}$(basicity case) generated in the gas phase, where $\mathrm{AH}$ (or $\mathrm{B}$ ) is the paracetamol, $\mathrm{A}_{\text {ref(i) }} \mathrm{H}$ (or $\mathrm{B}_{\text {ref(i) }}$ ) is a set of reference compounds with known $G A$ (or $G B$ ) values. The clusters $\left[\mathrm{A} \cdot \mathrm{H} \cdot \mathrm{A}_{\text {ref(i) }}\right]^{-}\left(\right.$or $\left.\left[\mathrm{B} \cdot \mathrm{H} \cdot \mathrm{B}_{\text {ref(i) }}\right]^{+}\right)$are fragmented by collision-induced dissociation (CID) in a collision cell of the spectrometer to yield the corresponding monomeric anions (or cations) of the sample $\mathrm{A}^{-}$(or $\mathrm{BH}^{+}$) and the reference $\mathrm{A}_{\text {ref(i) }}{ }^{-}$(or $\mathrm{B}_{\text {ref(i) }} \mathrm{H}^{+}$), via the two competitive dissociation channels with rate constants $k$ and $k_{i}$, respectively. If secondary fragmentation is negligible, the abundance ratio of these fragment ions is equal to the ratio of the two dissociation rate constants, $k$ and $k_{\mathrm{i}}$ (Scheme 1). 

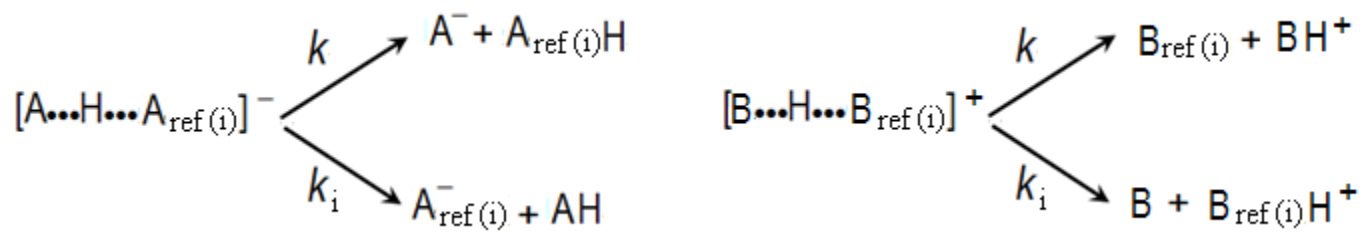

\section{Scheme 1}

With the assumption that there are no-reverse activation energy-barriers, the acidity and basicity of sample studied are related, respectively, by a linear equations $3 \mathrm{a}$ and $3 \mathrm{~b}$, which statistical procedure has been developed by Armentrout, ${ }^{8}$ and they can be expressed as,

$$
\begin{aligned}
& \left(\begin{array}{l}
k \\
k_{i}
\end{array}\right)=\pi^{\ln } \frac{\left[\mathrm{A}^{-}\right]}{\left[\mathrm{A}_{\text {reffi }}^{-}\right]}=\frac{\left(\Delta_{\text {acid }} H_{\text {reffi }}^{0}-\Delta_{\text {acid }} H_{\text {ref }}^{\text {avg }}\right)}{R T_{\text {eff }}}-\left[\frac{\Delta_{\text {acid }} H^{0}-\Delta_{\text {acid }} H_{\text {ref }}^{\text {avg }}}{R T_{\text {eff }}}-\frac{\Delta\left(\Delta S^{0}\right)}{R}\right] \\
& \ln \frac{\left[\mathrm{BH}^{+}\right]}{\left[\mathrm{B}_{\text {reff(i) }} \mathrm{H}^{+}\right]}=-\frac{\left(P A_{\mathrm{reff}(\mathrm{i})}-P A_{\mathrm{ref}}^{\mathrm{avg}}\right)}{R T_{\text {eff }}}+\left[\frac{P A-P A_{\mathrm{ref}}^{\mathrm{avg}}}{R T_{\mathrm{eff}}}-\frac{\Delta\left(\Delta S^{0}\right)}{R}\right]
\end{aligned}
$$

where, $\Delta_{\text {acid }} H_{\text {ref }}^{\text {avg }}$ and $P A_{\text {ref }}^{\text {avg }}$ are the average of the deprotonation enthalpy and proton affinity of the reference compounds, respectively; $T_{\text {eff }}$ is an "effective temperature" 21,22 related to the excitation energy of the dissociating $\left[\mathrm{A} \cdot \mathrm{H} \cdot \mathrm{A}_{\operatorname{ref}(\mathrm{i})}\right]^{-}$or $\left[\mathrm{B} \cdot \mathrm{H} \cdot \mathrm{B}_{\mathrm{ref}(\mathrm{i})}\right]^{+}$heterodimers. The entropic term $\Delta\left(\Delta S^{0}\right)$ can be expressed as the difference in the deprotonation (protonation) entropies of the two acids (or bases), ${ }^{23,24} \Delta\left(\Delta S^{0}\right) \approx \Delta_{\text {aci }} S^{0}-\Delta_{\text {aci }} S_{\text {ref }(}^{0}\left(\right.$ or $\approx \Delta_{\mathrm{p}} S^{0}-\Delta_{\mathrm{p}} S_{\text {ref(i) }}^{0}$ ). If the reference compounds have similar deprotonation (protonation) entropies, the last term can be substituted for the corresponding average entropy, as $\Delta\left(\Delta S^{0}\right) \approx \Delta_{\text {aci }} S^{0}-\Delta_{\text {aci }} S_{\text {ref }}^{\text {avई }} \quad$ (acidity) or $\Delta\left(\Delta S^{0}\right) \approx \Delta_{\mathrm{p}} S^{0}-\Delta_{\mathrm{p}} S_{\text {ref }}^{\text {avg }}$ (basicity). We now have three unknown variables in eq. $3 \mathrm{a}\left(\Delta_{\text {acid }} H^{0}\right.$, $R T_{\text {eff }}$ and $\left.\Delta_{\text {acid }} S^{0}\right)$ or in eq. $3 \mathrm{~b}\left(P A, R T_{\text {eff }}\right.$ and $\left.\Delta_{\mathrm{p}} S^{0}\right)$. These quantities can be obtained for each case from two sets of thermokinetic plots based on equation $3 \mathrm{a}$ (or $3 \mathrm{~b}$ ). The first set is the linear plot of $\ln \left(k / k_{i}\right) v s\left(\Delta_{\text {acid }} H_{\text {ref(i) }}^{0}-\Delta_{\text {aci d }} H_{\text {ref }}^{\text {avg }}\right)$ or $v s\left(P A_{\text {ref(i) }}-P A_{\text {ref }}^{\text {avg }}\right)$ using data collected from a series of experiments under different collision energies. The resulting plots give a series of straight lines characterized by a slope equal to $1 / R T_{\text {eff }}$ (acidity) or $-1 / R T_{\text {eff }}$ (basicity) and a Y-intercept including terms expressed between brackets in the equations $3 \mathrm{a}$ and $3 \mathrm{~b}$. In the second thermokinetic plot, the values of the intercepts obtained in the first graph are plotted against $1 / R T_{\text {eff }}$ values (obtained before). The new plot yields a second straight line with a slope given by $\left(\Delta_{\text {acid }} H^{0}-\Delta_{\text {acid }} H_{\text {ref }}^{\text {avg }}\right)$ (acidity) or by $\left(P A-P A_{\text {ref }}^{\text {avg }}\right.$ ) (basicity) and an intercept given by $\Delta\left(\Delta S^{0}\right) / R$. Finally, the gas-phase acidity $G A$ or basicity $G B$ of sample studied is derived from equation, $G A=\Delta_{\text {aci }} H^{0}-T\left(\Delta_{\text {aci }} S^{0}\right)$ and $G B=P A-T\left(\Delta_{\mathrm{p}} S^{0}\right)$ where $T=298.15 \mathrm{~K}$. 


\section{Experimental deprotonation (acidity) thermochemistry of paracetamol}

To determine the gas-phase acidity of paracetamol applying the EKM method (equation 3a), we have chosen four reference acids $\mathrm{A}_{\text {ref(i) }} \mathrm{H}$ with $G A$ s ranging from 1388.4 to $1419.4 \mathrm{~kJ} \cdot \mathrm{mol}^{-1}$ (see supplementary material): 2,3,5,6-tetramethylbenzoic acid, 2,2,2-trifluoroacetamide, trimethylacetic acid, isobutyric acid. The CID branching ratio of the product ions were recorded at eight collision energies $\left(\mathrm{E}_{\mathrm{cm}}\right)$, from 1.75 to $3.75 \mathrm{eV}$. The natural logarithms of the branching ratios, $\ln \left(\left[\mathrm{A}^{-}\right] /\left[\mathrm{A}_{\mathrm{ref}(\mathrm{i})}^{-}\right]\right)$, were plotted against the values of $\left(\Delta_{\text {aci }} H_{\mathrm{ref}(\mathrm{i})}^{0}-\Delta_{\text {aci }} H_{\mathrm{ref}}^{\text {avg }}\right)$ (first thermokinetic plot depicted in Fig.1a) where $\Delta_{\text {acid }} H_{\text {ref }}^{\text {avg }}=1437.1 \pm 8.8 \mathrm{~kJ} \cdot \mathrm{mol}^{-1}$ is the average of deprotonation enthalpies of reference acids (see supplementary material). The data are fitted by a set of eight regression lines, each one corresponding to experiments done with collision energies $E_{\mathrm{cm}}$. The second thermokinetic plot (Figure 1a) is generated by plotting the negative Y-intercept values (related with the expression between brackets in the equation $3 a$ ) vs slopes $1 / R T_{\text {eff }}$ obtained from the results of the first graph. The deprotonation thermochemical values of paracetamol (Table 1) were derived from slope and negative $\mathrm{Y}$-intercept values of the linear fit of the second plot (see supplementary material): $\Delta_{\text {acid }} H^{0}=1430.3 \pm 8.8 \mathrm{~kJ} \cdot \mathrm{mol}^{-1}, \Delta_{\text {acid }} S^{0}=86.2 \pm$ $8.4 \mathrm{~J} \cdot \mathrm{mol}^{-1} \cdot \mathrm{K}^{-1}$ and $G A=1404.7 \pm 8.8 \mathrm{~kJ} \cdot \mathrm{mol}^{-1}$.

\section{Experimental protonation (basicity) thermochemistry of aracetamol}

Four compounds with $G B$ s ranging from 856.7 to $880.1 \mathrm{~kJ} \cdot \mathrm{mol}^{-1}$ (see supplementary material) were chosen as references: 1,2,3-triazole, pyrazole, 3-methylpyrazole, benzylamine. The CID branching ratio of the product ions were recorded at eight collision energies $\left(\mathrm{E}_{\mathrm{cm}}\right)$, from 0.75 to $3.0 \mathrm{eV}$. The corresponding first set thermokinetic plots (eq. 3b) $\ln \left(\left[\mathrm{BH}^{+}\right] /\left[\mathrm{B}_{\text {ref(i) }} \mathrm{H}^{+}\right]\right) v s$ $\left(P A_{\text {reffi }}-P A_{\text {ref }}^{\text {avg }}\right)$ is presented in Figure $1 \mathrm{~b}$. The proton affinity $P A$ of paracetamol was obtained from the second set of thermokinetic plot. It was generated from Y-intercepts values obtained from the first set of the plots against the corresponding slopes $1 / R T_{\text {eff. The protonation }}$ thermochemical values of paracetamol (Table 1) were derived from slope and Y-intercept values of the linear fit of the second plot (see supplementary material): $P A=909.4 \pm 8.4 \mathrm{~kJ} \cdot \mathrm{mol}^{-1}, \Delta_{\mathrm{p}} S^{0}$ $=132.8 \pm 8.4 \mathrm{~J} \cdot \mathrm{mol}^{-1} \cdot \mathrm{K}^{-1}$ and $G B=869.9 \pm 8.4 \mathrm{~kJ} \cdot \mathrm{mol}^{-1}$.

\section{Structural and energetic features of neutral, protonated and deprotonated paracetamol}

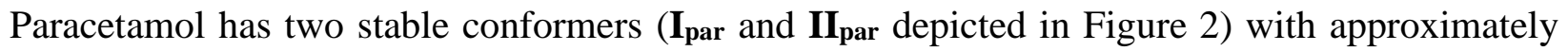

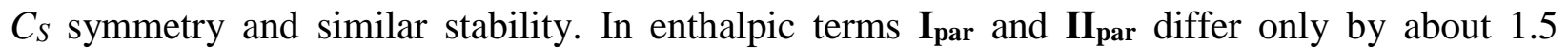
$\mathrm{kJ} \cdot \mathrm{mol}^{-1}$, the latter being less stable. Except for the hydrogens of the methyl group, the remaining fragments of each conformer are coplanar. Rotation of the hydroxyl group in $\mathbf{I}_{\text {par }}$ around the

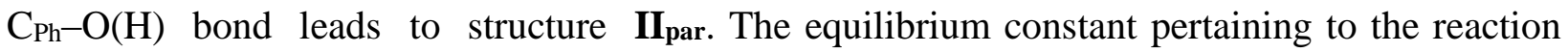

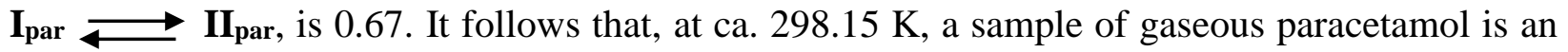
equilibrating mixture of approximately 60 and $40 \%$ of $\mathbf{I}_{\mathbf{p a r}}$ and $\mathbf{I I}_{\mathbf{p a r}}$, respectively. The values correspond to calculations at B3LYP/6-311++G(3df,2p) level of theory. 
(a) Acidity
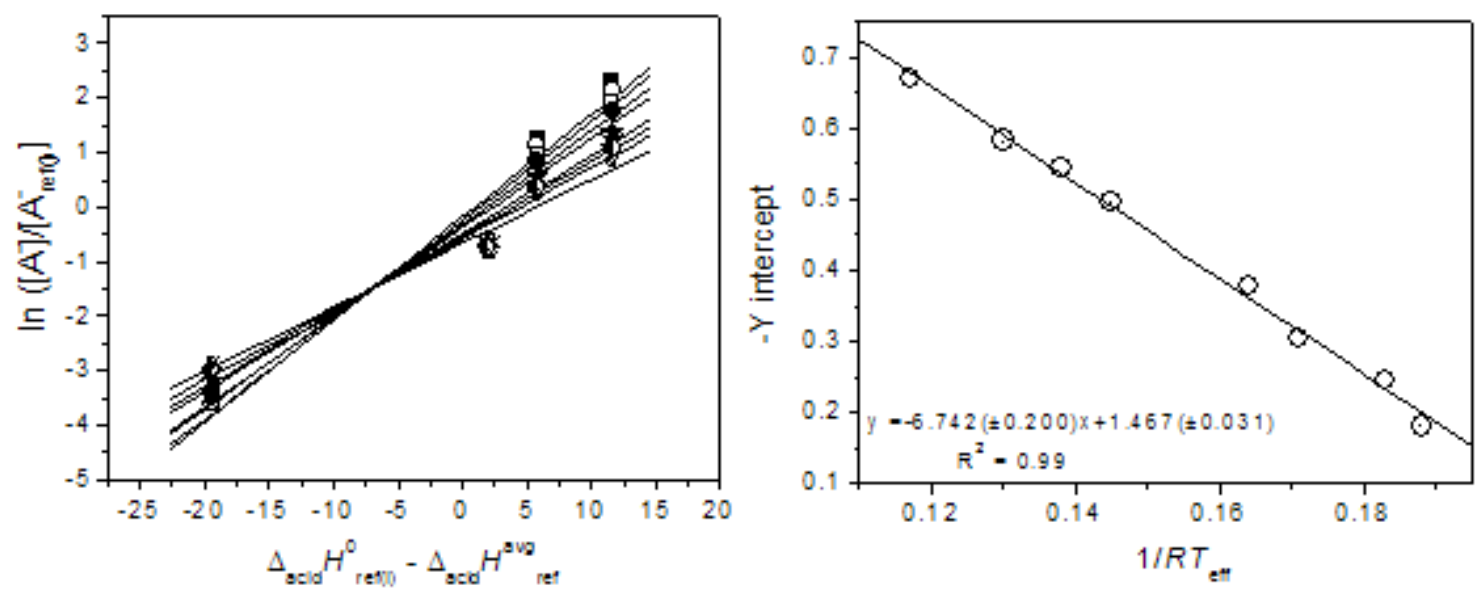

(b) Basicity
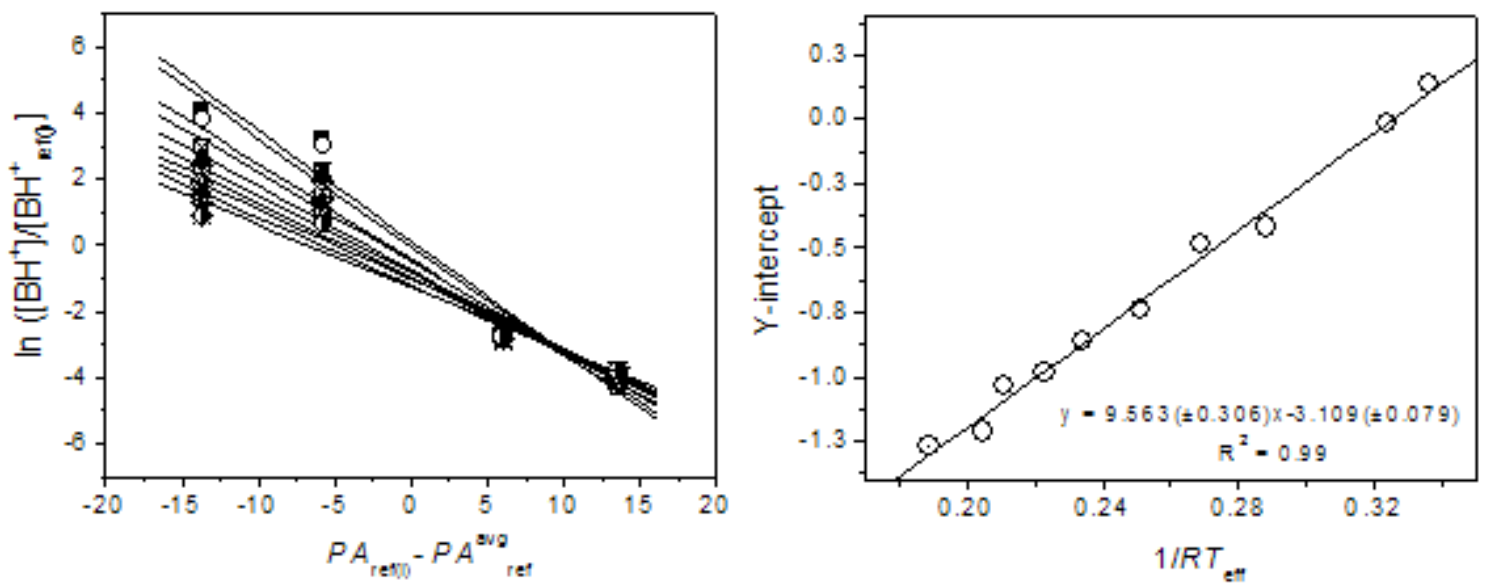

Figure 1. First (left) and second (right) sets of thermokinetic plots using data of CID dissociation of heterodimers (a) $\left[\mathrm{A} \cdot \mathrm{H} \cdot \mathrm{A}_{\mathrm{ref}(\mathrm{i})}\right]^{-}$and (b) $\left[\mathrm{B} \cdot \mathrm{H} \cdot \mathrm{B}_{\mathrm{ref}(\mathrm{i})}\right]^{+}$, where $\mathrm{AH}=\mathrm{B}=$ paracetamol and $\mathrm{AH}_{\text {ref(i), }} \mathrm{B}_{\text {ref(i) }}$ reference compounds.

The optimized geometries of paracetamol ions (deprotonated and protonated) show conformers resemble to corresponding neutral molecules (Figure 2). The structure of stable anion formed by $\mathrm{OH}$-deprotonation (oxyanion) shows little variations in geometrical parameters such as $\mathrm{C}=\mathrm{O}$ or $\mathrm{N}=\mathrm{C}$ bond lengths, while the $\mathrm{C}_{\mathrm{Ph}}-\mathrm{O}(\mathrm{H})$ bond length is significantly shortened (by $\sim 0.1 \AA$ ) upon deprotonation. This result indicates a strong increase of $\mathrm{C}_{\mathrm{Ph}}-\mathrm{O}$ bond due to the concentrating of negative charge particularly on its oxygen atom. In this context, it is interesting to mention that the results (IR in dissolution) obtained by Binev and col. ${ }^{25}$ show an increase of the wave number for $\mathrm{C}_{\mathrm{Ph}}-\mathrm{O}$ vibrational mode in paracetamol (monosodium-derivative) oxyanion, compared to that in neutral molecule. 
It is known ${ }^{26}$ that, in the gas phase, carbonyl compounds with heteroatoms endowed with lone pairs (potential basic sites) such as paracetamol, protonate on the carbonyl-oxygen. According with this fact, our theoretical calculations indicate this oxygen as the preferred protonation site rather than nitrogen. The optimized geometry of the protonated paracetamol shows two stable especies $\mathbf{I}_{\mathbf{p a r}} \mathrm{H}^{+}$and $\mathbf{I I}_{\mathbf{p a r}} \mathrm{H}^{+}$(Figure 2) resembling also neutral conformers $\mathbf{I}_{\text {par }}$ and $\mathbf{I I}_{\mathbf{p a r}}$, respectively. Both conformers have practically the same stability. Some interesting geometry features should be singled out for commenting: $\mathrm{i} /$ upon protonation, there is almost 0.1 $\AA$ elongation of $\mathrm{C}=\mathrm{O}$, which indicates that the $\mathrm{C}=\mathrm{O}$ linkage is difficult to stretch, but also clearly reflects a slight weakening due to the charge transfer toward the incoming proton. ii/ Upon protonation, the $\mathrm{C}=\mathrm{O}$ and $\mathrm{N}=\mathrm{C}$ bond lengths are shortened by $\sim 0.07 \AA$ and $0.03 \AA$. iii/ The $\mathrm{N}=\mathrm{C}_{\text {carbonyl }}-\mathrm{C}_{\text {methyl }}$ bond angle opens up (by $\sim 7^{\circ}$ ) upon protonation, due to the charge redistributions which take place within the molecule.

In Table 1 are compared the theoretical and experimental values of deprotonation and protonation thermochemical quantities. It is observed that there is reasonable agreement among these values, being particularly noticeable the excellent agreement between experimental and calculated values of basicity $G B$ (deviation less than $1.5 \mathrm{~kJ} \cdot \mathrm{mol}^{-1}$ ) and also of acidity $G A$ (deviation less than $\left.3.5 \mathrm{~kJ} \cdot \mathrm{mol}^{-1}\right)$ using 6-311++G(3df,2p) and 6-311++G(d,p) basis sets, respectively.

Table 1. Experimental and theoretical values of deprotonation and protonation thermochemical quantities of paracetamol

\begin{tabular}{cccc}
\hline & & \multicolumn{2}{c}{ Calculated/ B3LYP } \\
\cline { 3 - 4 } & Experimental & 6-311++G(d,p) & $6-311++\mathrm{G}(3 \mathrm{df}, 2 \mathrm{p})$ \\
\hline & & Acidity (deprotonation) \\
\hline$\Delta_{\text {acid }} G^{0}(G A) / \mathrm{kJ} \cdot \mathrm{mol}^{-1}$ & $1404.7 \pm 8.8$ & $1407.8^{\mathrm{a}}$ & $1412.9^{\mathrm{a}}$ \\
$\Delta_{\mathrm{acid}} H^{0} / \mathrm{kJ} \cdot \mathrm{mol}^{-1}$ & $1430.3 \pm 8.8$ & 1436.3 & 1440.7 \\
$\Delta_{\mathrm{acid}} S^{0} / \mathrm{J} \cdot \mathrm{mol}^{-1} \cdot \mathrm{K}^{-1}$ & $86.2 \pm 8.4$ & $96.2^{\mathrm{b}}$ & $93.2^{\mathrm{b}}$ \\
& & Basicity (protonation) \\
$\Delta_{\mathrm{p}} G^{0}(G B) / \mathrm{kJ} \cdot \mathrm{mol}^{-1}$ & $869.9 \pm 8.4$ & $864.6^{\mathrm{a}}$ & $868.5^{\mathrm{a}}$ \\
$\Delta_{\mathrm{p}} H^{0}(\mathrm{PA}) / \mathrm{kJ} \cdot \mathrm{mol}^{-1}$ & $909.4 \pm 8.4$ & 896.7 & 902.6 \\
$\Delta_{\mathrm{p}} S^{0} / \mathrm{J} \cdot \mathrm{mol}{ }^{-1} \cdot \mathrm{K}^{-1}$ & $132.8 \pm 8.4$ & $107.5^{\mathrm{b}}$ & $114.6^{\mathrm{b}}$ \\
\hline
\end{tabular}

${ }^{\text {a }}$ Determined using the expression $\Delta G^{0}=\Delta H^{0}-T \Delta S^{0}$, with $T=298.15 \mathrm{~K}$. ${ }^{\mathrm{b}}$ Calculated taking into account the contribution of populations of neutral (and protonated) conformers.

Furthermore, by using the experimental values of $P A$ and $\Delta_{\text {acid }} H^{0}$ determined in this work, together with enthalpies of formation of paracetamol, $\Delta_{\mathrm{f}} H^{0}(\mathrm{~g})=-280.5 \pm 1.9 \mathrm{~kJ} \cdot \mathrm{mol}^{-1}$ (taken 
from ref. 3) and of $\mathrm{H}^{+}, \Delta_{\mathrm{f}} H^{0}\left(\mathrm{H}^{+}, \mathrm{g}\right)=1536.25 \pm 0.04 \mathrm{~kJ} \cdot \mathrm{mol}^{-1}$ (taken from $\mathrm{JANAF}^{27}$ ), allowed us to estimate (using equations 1 and 2) purely experimental values of enthalpy of formation of deprotonated (oxyanion) and protonated paracetamol as: $\Delta_{\mathrm{f}} H^{0}$ (oxyanion, $\left.\mathrm{g}\right)=-386.4 \pm 9.0$ $\mathrm{kJ} \cdot \mathrm{mol}^{-1}$ and $\Delta_{\mathrm{f}} H^{0}($ Par-prot, $\mathrm{g})=346.3 \pm 8.6 \mathrm{~kJ} \cdot \mathrm{mol}^{-1}$, respectively.

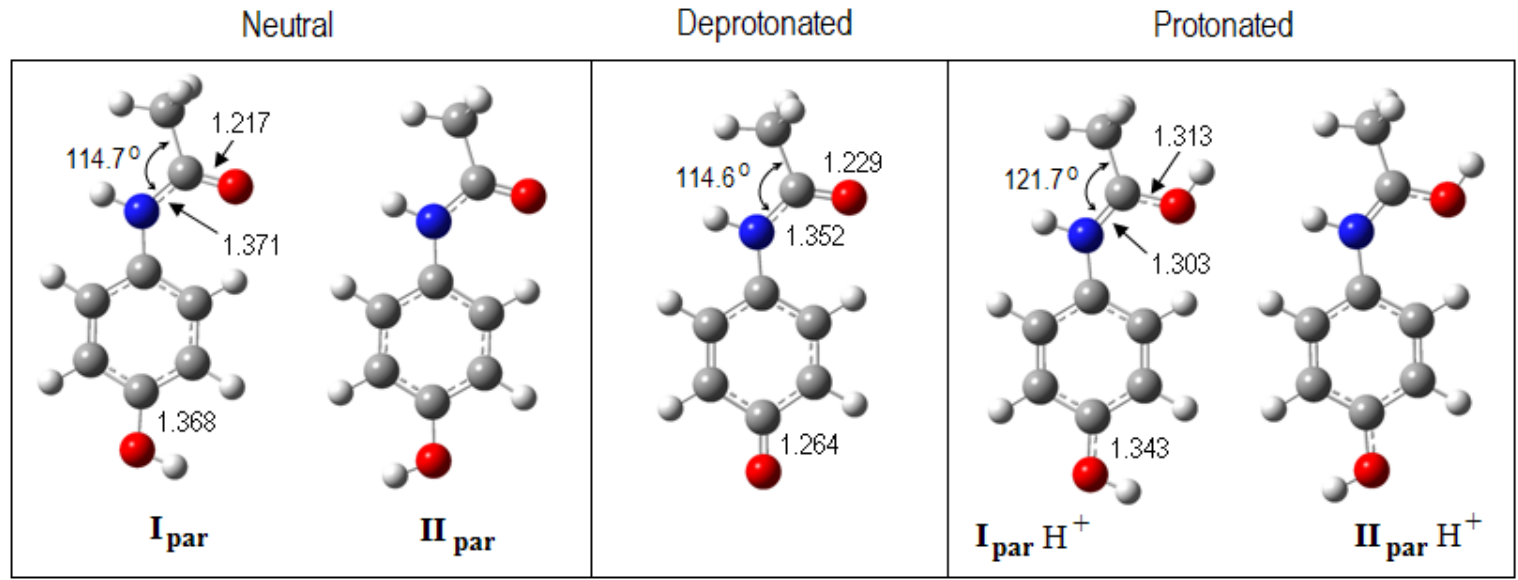

Figure 2. Molecular geometry for stable conformers of neutral, deprotonated and protonated paracetamol optimized at the B3LYP/6-311++G(3df,2p) level of theory. Interatomic distances in A.

\section{Conclusions}

The experimental and theoretical investigation of the deprotonation (acidity) and protonation (basicity) thermochemistry of the paracetamol molecule was reported in this work. We have employed the Extended Kinetic Method (EKM) using ESI-triple-quadrupole mass spectrometry as the experimental technique, as well as quantum chemical calculations at the B3LYP level of theory. Relevant and consistent set thermochemical data have been determined for this molecule and the resulting ions, formed by deprotonation of the $\mathrm{OH}$ group (oxyanion) or by protonation on the $\mathrm{C}=\mathrm{O}$ group (cation). The proton affinity, basicity, deprotonation enthalpy and acidity, in the gas phase, for paracetamol were determined to be, respectively in $\mathrm{kJ} \cdot \mathrm{mol}^{-1}: P A=909.4 \pm 8.4, G B$ $=869.9 \pm 8.4 ; \Delta_{\text {acid }} H^{0}=1430.3 \pm 8.8$ and $G A=1404.7 \pm 8.8$. We also have derived the enthalpy of formation $\Delta_{\mathrm{f}} H^{0}(\mathrm{~g})$ of protonated and deprotonated paracetamol (in $\mathrm{kJ} \cdot \mathrm{mol}^{-1}$ ): $-386.4 \pm 9.0$ and $346.3 \pm 8.6$, respectively.

Finally, it is important to mention that our theoretical calculations provided interesting results which enabled us to confirm the consistency of our experimental measurements, being particularly noticeable the excellent agreement between experimental and calculated values of basicity $G B$ and also of the acidity $G A$ values of paracetamol. 


\section{Experimental and Computational Section}

Materials. Paracetamol and reference compounds (bases and acids) were purchased from SigmaAldrich and Alfa Aesar and used without further purification. The reference compounds were chosen on the basis of their similar $G A$ or $G B^{28}$ to that calculated for paracetamol.

General. The experiments were carried out on a triple quadrupole mass spectrometer Agilent/Varian 320 equipped with electrospray ionization (ESI) source. Stock solutions $\left(\sim 10^{-3} \mathrm{M}\right.$, in methanol) of paracetamol and the desired reference compound were mixed in appropriate volume ratios $(\sim 1: 1)$, and further diluted also with methanol to achieve a final concentration of $\sim 10^{-4} \mathrm{M}$ for both compounds. The solutions were directly infused into the ESI ionization source in the negative (acidity) or positive (basicity) modes, at flow rates of $10 \mu \mathrm{L} / \mathrm{min}$. The temperature of the drying gas and the solvents were optimized in order to promote the formation of more intensive signal of proton bound heterodimeric ions. The cluster ions were isolated in the first quadrupole, underwent collision induced dissociation (CID) in the second quadrupole and the resulting fragments were analyzed in the third quadrupole. CID experiments were performed using argon as a collision gas ( 0.2 mTorr) at various ion kinetic energies in the collision cell. The center of mass energy $\left(E_{c m}\right)$ was calculated as: $E_{c m}=E_{l a b}[m /(M+m)]$ where $E_{l a b}$ is the ion kinetic energy in the laboratory frame, $\mathrm{m}$ is the mass of the collision gas and $\mathrm{M}$ is the mass of the heterodimeric cluster ion.

Computational Details. The quantum chemical calculations were carried out using the Gaussian 09 package. $^{29}$ The geometries of paracetamol neutral molecule as well as its protonated or deprotonated ions were optimized by using density functional theory (DFT), with the Becke 3parameter and Lee-Yang-Parr (B3LYP) functional, ${ }^{30,31}$ in conjunction with a 6-311++G(d,p) and $6-311++G(3 d f, 2 p)$ basis sets without symmetry restrictions. Harmonic vibrational frequencies were also calculated at the same levels and used without scaling.

$G A$ and $G B$ values of paracetamol were computed as the thermal population weighted average of the thermochemical quantities of their neutral and ionic conformers. The thermally weighted deprotonation (or protonation) entropies were obtained from $\Delta_{\text {acid }(p)} S^{0}=\sum_{1}^{N} x_{i}\left(S^{0}\right)_{i}-R \sum_{i}^{N} x_{i} \ln x_{i}$ where the $x_{i}$ are the mole fractions of the conformers.

\section{Acknowledgments}

This work has been supported by the Spanish DGI Project No. CTQ 2009-13652. A.F.L. gratefully acknowledges the support of CNPq-Brazil. 


\section{Supporting information}

See Supplementary material for thermochemical data of reference compounds and experimental procedures.

\section{References}

1. Singh, T. P.; Bhat, T. N.; Vijayan, M. Current Sci. 1973, 42, 384.

2. Nichols, G.; Frampton, C. S. J. Pharm. Sci. 1998, 87, 684.

http://dx.doi.org/10.1021/js970483d

PMid:9607944

3. Peterson, M. L.; Morissette, S. L.; McNulty, C.; Goldsweig, A.; Shaw, P.; LeQuesne, M.; Monagle, J.; Encina, N.; Marchionna, J.; Johnson, A.; Gonzalez-Zugasti, J.; Lemmo, A. V.; Ellis, S. J.; Cima, M. J.; Almarsson, Ö. J. Am. Chem. Soc. 2002, 124, 10958. http://dx.doi.org/10.1021/ja020751w

4. Boldyreva, E.; Drebushchak, V. A.; Paukov, I. E.; Kovalevskaya, Y.; Drebushchak, T. J. Therm. Anal. Calorim. 2004, 77, 607. http://dx.doi.org/10.1023/B:JTAN.0000038998.47606.27

5. Picciochi, R.; Diogo, H.; Minas da Piedade, M. J. Therm. Anal. Calorim. 2010, 100, 391. http://dx.doi.org/10.1007/s10973-009-0634-y

6. Cheng, X. H.; Wu, Z. C.; Fenselau, C. J. Am. Chem. Soc. 1993, 115, 4844. http://dx.doi.org/10.1021/ja00064a052

7. Cerda, B. A.; Wesdemiotis, C. J. Am. Chem. Soc. 1996, 118, 11884. http://dx.doi.org/10.1021/ja9613421

8. Armentrout, P. B. J. Am. Soc. Mass Spectrom. 2000, 11, 371. http://dx.doi.org/10.1016/S1044-0305(00)00102-1

9. Zheng, X.; Cooks, R. G. J. Phys. Chem. A 2002, 106, 9939. http://dx.doi.org/10.1021/jp020595f

10. Ervin, K. M. J. Mass Spectrom. 2002, 13, 435.

11. Drahos, L.; Vékey, K. J. Mass Spectrom. 2003, 38, 1025. http://dx.doi.org/10.1002/jms.538 PMid:14595853

12. Ervin, K. M.; Armentrout, P. B. J. Mass Spectrom. 2004, 39, 1004. http://dx.doi.org/10.1002/jms.682 PMid:15386748

13. Drahos, L.; Peltz, C.; Vékey, K. J. Mass Spectrom. 2004, 39, 1016. http://dx.doi.org/10.1002/jms.683 PMid:15386747 
14. Bouchoux, G. Mass Spectrom. Rev. 2007, 26, 775.

http://dx.doi.org/10.1002/mas.20151

PMid:17854059

15. Lago, A. F.; Jimenez, P.; Herrero, R.; Davalos, J. Z.; Abboud, J. L. M. J. Phys. Chem. A 2008, 112, 3201.

http://dx.doi.org/10.1021/jp7111999

PMid:18341312

16. Dávalos, J. Z.; Guerrero, A.; Herrero, R.; Jimenez, P.; Chana, A.; Abboud, J. L. M.; Lima, C. F. R. A. C.; Santos, L. M. N. B. F.; Lago, A. F. J. Org. Chem. 2010, 75, 2564.

http://dx.doi.org/10.1021/jo100085b

PMid:20297783

17. Cooks, R. G.; Kruger, T. L. J. Am. Chem. Soc. 1977, 99, 1279.

http://dx.doi.org/10.1021/ja00446a059

18. Graham Cooks, R.; Patrick, J. S.; Kotiaho, T.; McLuckey, S. A. Mass Spectrom. Rev. 1994, $13,287$.

http://dx.doi.org/10.1002/mas.1280130402

19. Cooks, R. G.; Wong, P. S. H. Acc. Chem. Res. 1998, 31, 379. http://dx.doi.org/10.1021/ar960242x

20. Cooks, R. G.; Koskinen, J. T.; Thomas, P. D. J. Mass Spectrom. 1999, 34, 85. http://dx.doi.org/10.1002/(SICI)1096-9888(199902)34:2<85::AID-JMS795>3.0.CO;2-\#

21. Ervin, K. M. Int. J. Mass Spectrom. 2000, 195-196, 271. http://dx.doi.org/10.1016/S1387-3806(99)00176-1

22. Drahos, L.; Vékey, K. J. Mass Spectrom. 1999, 34, 79. http://dx.doi.org/10.1002/(SICI)1096-9888(199902)34:2<79::AID-JMS793>3.0.CO;2-V

23. Ren, J.; Tan, J. P.; Harper, R. T. J. Phys. Chem. A 2009, 113, 10903. http://dx.doi.org/10.1021/jp903594a PMid:19754094

24. Mukherjee, S.; Ren, J. J. Am. Soc. Mass Spectrom. 2010, 21, 1720. http://dx.doi.org/10.1016/j.jasms.2010.06.002 PMid:20621504

25. Binev, I. G.; Vassileva-Boyadjieva, P.; Binev, Y. I. J. Mol. Struct. 1998, 447, 235. http://dx.doi.org/10.1016/S0022-2860(98)00302-0

26. Taft, R. W.; Topsom, R. D. The Nature and Analysis of Substitutent Electronic Effects.Progress in Physical Organic Chemistry: John Wiley \& Sons, Inc., 1987; Vol. 16; pp 1 .

27. Chase, J., M.W. NIST-JANAF Thermochemical Tables, 4th Ed. J. Phys. Chem. Ref. Data 1998; Vol. Monograph 9.

28. NIST Chemistry Webbook. Standard Reference Database Number 69; P.J. Linstrom, W.G. Mallard, Release June 2005: National Institute of Standards and Technology, Gaithersburg MD, 20899 (http://webbook.nst.gov ), 2012. 
29. Frisch, M. J.; Trucks, G. W.; Schlegel, H. B.; Scuseria, G. E.; Robb, M. A.; Cheeseman, J. R.; Scalmani, G.; Barone, V.; Mennucci, B.; Petersson, G. A.; Nakatsuji, H.; Caricato, M.; Li, X.; Hratchian, H. P.; Izmaylov, A. F.; Bloino, J.; Zheng, G.; Sonnenberg, J. L.; Hada, M.; Ehara, M.; Toyota, K.; Fukuda, R.; Hasegawa, J.; Ishida, M.; Nakajima, T.; Honda, Y.; Kitao, O.; Nakai, H.; Vreven, T.; Montgomery, J. A.; Peralta, J. E.; Ogliaro, F.; Bearpark, M.; Heyd, J. J.; Brothers, E.; Kudin, K. N.; Staroverov, V. N.; Kobayashi, R.; Normand, J.; Raghavachari, K.; Rendell, A.; Burant, J. C.; Iyengar, S. S.; Tomasi, J.; Cossi, M.; Rega, N.; Millam, J. M.; Klene, M.; Knox, J. E.; Cross, J. B.; Bakken, V.; Adamo, C.; Jaramillo, J.; Gomperts, R.; Stratmann, R. E.; Yazyev, O.; Austin, A. J.; Cammi, R.; Pomelli, C.; Ochterski, J. W.; Martin, R. L.; Morokuma, K.; Zakrzewski, V. G.; Voth, G. A.; Salvador, P.; Dannenberg, J. J.; Dapprich, S.; Daniels, A. D.; Farkas; Foresman, J. B.; Ortiz, J. V.; Cioslowski, J.; Fox, D. J. Gaussian 09, Revision A.01 Wallingford CT, 2009.

30. Becke, A. D. J. Chem. Phys. 1993, 98, 5648.

31. Lee, C.; Yang, W.; Parr, R. G. Phys. Rev. B 1988, 37, 785.

http://dx.doi.org/10.1103/PhysRevB.37.785 